\title{
Conservation Efforts of Asian Wild Water Buffalo
}

\author{
Pramod Kumar Kherwar ${ }^{1}$ and Ajaya Bhattarai ${ }^{2, *}$
}

\begin{abstract}
${ }^{1}$ Mahendra Morang Adarsh Multiple Campus (Tribhuvan University), Department of Zoology, Biratnagar, Nepal

${ }^{2}$ Mahendra Morang Adarsh Multiple Campus (Tribhuvan University), Department of Chemistry, Biratnagar, Nepal
\end{abstract}

\begin{abstract}
Asian Wild Water Buffalo with the scientific name Bubalus bubalis arnee is recorded as an imperiled species in the International Union for Conservation of Nature (IUCN's) Red List of Threatened Species wetland-subordinate. More number Wild Water Buffalo in Nepal are found at the Koshi Tappu Wildlife Reserve (KTWR), situated on the floodplain of the Koshi River in Province 1. This species is in danger because of a high anthropogenic pressing factor going from natural surroundings weakening to hybridization with homegrown Buffalo. Various preservation and work mediations have been attempted to shield the biodiversity, especially the wild buffalo populace in the KTWR. The people group-based supportable administration approach profiting both protection and work of neighborhood individuals is important to guarantee the drawn-out preservation of the species. But it is not happening, so the Government of Nepal translocated 18 Wild Water Buffaloes to Chitwan National Park, and the environment is not suitable for them. There is the possibility to translocate Wild Water Buffaloes in the Babai flood plain of Bardia National Park for conservation.
\end{abstract}

Keywords: Bubalus bubalis arnee, KTWR, IUCN.

\section{INTRODUCTION}

Asian Wild Water Buffalo was available in Royal Chitwan National Park in the mid-1960s however got terminated there, likely because of sicknesses conveyed by homegrown cows and Buffalo brought by outsiders settling the region after the eradication of malaria [1]. So, the Government of Nepal (GoN) established KTWR, an IUCN Category IV protected area [2], in 1976 with an area of $175 \mathrm{Km}^{2}$ of Terai as the physiographic zone to protect the Nepalese Wild Buffalo [1, 3].

It was believed that Wild Water Buffalo, locally called Arna, an older adult above 100 years of age from the indigenous Yadav community. Mr. Ragghu Yadav from Trihut rural municipality ward no. 1, Dhanpuri village, Saptari district, who used to stay in the Reserve for months till 2005 from herding domestic buffaloes, said that three female buffaloes, different from his local breeds, came from the Indian side and settled in the Reserve. The progeny of those buffaloes are today's Wild Water Buffaloes [4]. Recognizable proof of hereditarily unadulterated wild individuals is significant for distinguishing creatures for movement to different territories inside their previous reach. Phylogenetic connections inferred through a diminished middle organization and greatest stinginess examinations reconfirmed the hereditary idea of the Wild Water Buffalo [5]. In 2016, 433 Wild Buffaloes were counted in KTWR [6].

*Address correspondence to this author at the Mahendra Morang Adarsh Multiple Campus (Tribhuvan University), Department of Chemistry, Biratnagar, Nepal; E-mail: bkajaya@yahoo.com, ajaya.bhattarai@mmamc.tu.edu.np
Being the lone living space, the species are inconsistent in danger of being terminated from Nepal if normal disasters, for example, floods, fires, and pandemics, were to happen inside the environment. Henceforth, the essential goal of the movement of wild water Buffalo was to build up a second biologically feasible populace in Chitwan National Park, consequently giving them a battling chance if there should arise common catastrophes. Territory misfortune, corruption, and environmental changeactuated debacles are different kinds of dangers to the populace. The movement will likewise assist with giving a maintainable protection plan to Arna. Also, the nearby partners from and around Chitwan National Park will profit from the advancement of eco-the travel industry comparable to Wild Water Buffalo.

Set up in 1976 more than $65 \mathrm{~km}^{2}$; reached out to its current size in 1980 by including the flood fields of the Koshi River to ensure the last remainder populace of wild water-buffaloes Declared a Ramsar site on 17 December 1987 [6], and buffer zone in 2004 [1].

Safeguarding of the last remainder populace of the fundamentally imperiled wild water buffaloes and their territories; an extensive administration procedure structure and plan has been readied, including key KTWR partners-built up a proposition for the movement of the wild water-buffalo inside Nepal [6]. Around 500 homegrown wild buffaloes have been cleared from the Reserve. Different sorts of exploration have been done at KTWR under DNPWC: Research did from 1999-2000 remembered reads for crop harm and domesticated animals theft, riverine woods, the 
Arna territory, and the swamp partridge. Three examinations directed from 2000-2001 evaluated the financial aspects of the wild Buffalo, planned difficulties in the Reserve buffer zone, and a 'nilgai' (blue bull) study [7]. The Wild water buffalo (Bubalus arnee) has increased from 63 in 1976 [8] to 441 in 2018 [4], as in Table 1.

Given the precarious existence of Wild Buffalo within KTWR, several wildlife conservationists have emphasized the need to translocate a sufficient number of individuals to sites within their indigenous range. Chitwan National Park had this species [1] and has extensive grassland areas and much larger riverine habitats with sufficient upland areas that are not prone to flooding, compared to KTWR [9]. For these reasons, 18 Wild Buffaloes were translocated to Chitwan National Park from KTWR recently, and more need to be moved soon $[10,11]$.

A portion of the individuals has been moved to Chitwan National Park of Central Nepal. However, the endurance rate isn't acceptable. An investigation was directed in the Babai flood plain of Bardia National Park (BNP) to recognize reasonable territory for wild water buffalo dependent on natural surroundings boundaries of KTWR. The examination utilized both the geospatial and vegetation investigation strategy [12]. Babai flood plain of BNP is a decently reasonable living space for wild water buffalo. Grassland and wetland executives and investigation of different boundaries, for example, atmosphere and prey-hunter relationship are prescribed before settling on the choice to move wild water buffalo to the Babai flood plain of BNP.

\section{WILD WATER BUFFALO CONSERVATION}

\section{Status}

The Wild water Buffalo Bubalus arnee (Kerr, 1792), also known as Arna in Nepali, is a robust animal distributed in Europe and Southern Asia in the Pleistocene age was later restricted to Southeast Asia [13]. At present, the Asiatic Wild Water Buffalo occurs in India, Nepal, Bhutan, Myanmar, Thailand, and Cambodia [13].

In 2016, 18 individuals of Wild Water Buffaloes were translocated from KTWR to Chitwan National Park. Translocation was carried out by a team of 60 people, including three veterinarians and 12 wildlife technicians led by DNPWC with support from the World Wildlife Fund Nepal, the USAID-supported Hariyo Ban Program, National Trust for Nature Conservation, Biodiversity Conservation Centre (NTNCBCC), and the Zoological Society of London (Nepal)[5].

To establish a second viable population, 13 Wild Water Buffalo (10 F, 3M) were translocated to Chitwan National Park from Jan 27-Feb 7, 2017. In Nepal, it has been accorded the highest degree of protection under the National Parks and Wildlife Conservation Act, 1973. Outside Nepal, Wild Water Buffalo is legally protected in Bhutan, India, and Thailand. A recent census

Table 1: Population Trend of Wild Water Buffalo Since 1976

\begin{tabular}{|c|c|c|c|c|c|c|}
\hline \multirow{2}{*}{ Year } & \multicolumn{2}{|c|}{ Adults } & \multicolumn{2}{|c|}{ Calves } & \multirow{2}{*}{ Total } & \multirow{2}{*}{$\begin{array}{l}\text { Calves to buffalo cows } \\
\text { ratio }\end{array}$} \\
\hline & Male & Female & 2nd year & 1st year & & \\
\hline 1976 & 12 & 18 & 22 & 11 & 63 & 0.61 \\
\hline 1987 & 32 & 29 & 14 & 16 & 91 & 0.55 \\
\hline 1988 & 37 & 33 & 8 & 15 & 93 & 0.45 \\
\hline 2000 & 56 & 53 & 17 & 19 & 145 & 0.36 \\
\hline 2004 & 54 & 63 & 24 & 18 & 159 & 0.29 \\
\hline 2009 & 55 & 119 & 22 & 23 & 219 & 0.19 \\
\hline 2010 & 57 & 108 & 24 & 26 & 215 & 0.22 \\
\hline 2011 & 66 & 117 & 15 & 39 & 237 & 0.33 \\
\hline 2012 & 67 & 119 & 37 & 36 & 259 & 0.30 \\
\hline 2014 & 128 & 142 & 25 & 32 & 327 & 0.23 \\
\hline 2016 & 120 & 182 & 50 & 81 & 433 & 0.45 \\
\hline 2018 & 137 & 191 & 75 & 38 & 441 & 0.20 \\
\hline
\end{tabular}


conducted in 2018 recorded 441 individuals with 191 adult females. The population is in an increasing trend since the Reserve establishment from 63 in 1976 (Table 1). This species occasionally moves into adjoining areas in the buffer zone in Saptari, Sunsari, and Udaypur districts on either side of the Koshi River of the Reserve. The global population of Wild Water Buffalo is estimated to be less than 4,000 individuals.

The grown-up sex proportion was female-one-sided in 1976, 2004 [14], and again in 2009, yet male-onesided in the three intervening censuses. An enormous well-evolved creature populaces have female-onesided grown-up sex proportions [14,15]. The calf/cow proportion has diminished essentially throughout the entire period. The calf/cow proportion detailed for Arna in KTWR in all cases is steady with the known scope of characteristic interbirth spans for homegrown Buffalo recorded in different investigations. These statistics also show the pattern going down in calf/cows' animal proportion [16]. Subsequently, the evident decrease in calf/cow proportion is perhaps credited either because of the decrease in birth rate or decay of the reproducing populaces; or expansion in poaching or burglary of Arna calf or passing because of different reasons. The number of inhabitants in feral cattle was discovered to be higher than the assessed populace in 2000 [17], which could be ascribed to the absence of law authorization/appropriate administration.

\section{Conservation Efforts}

Protection of its prime habitat has been ensured through security strengthening by army deployment in the posts and regular patrolling. Sweep operation and intelligence-based patrolling have been carried out to control the grazing of domestic buffaloes in their habitat. Monitoring and population census have been conducted periodically to update its status.

\section{PARK-PEOPLE CONFLICT}

KTWR is highly impacted by human activities, and there is increasing conflict between the reserve authorities and people living in the area" crop damage, depredation of livestock, the human toll, and resentment arising from reserve regulation are the four basic causes of "Park-People conflict [18]. Due to the increased protection of wildlife crops, free moving wild animals' damage on peripheral agricultural land is extensive. This turns people against conservation because the loss of crops became a heavy burden on an individual's economy. Generally, the grasslands area is the main food habitat of wild Buffalo. However, the plants are eaten by wild Buffalo and their food preference, as shown in Table 2.

The study results indicated that the vast majority have a negative mentality about saving despite the current immediate and indirect advantages. These perspectives are showed repeatedly. Numerous

Table 2: Plants are Eaten by Wild Water Buffalo

\begin{tabular}{|c|c|c|}
\hline Scientific Name & English Name & Food Preference \\
\hline Imperata Cylindria & Siru & ++++ \\
\hline Saccharum spontaneum & Kans grass & ++++ \\
\hline Cynodon dactylon & Bermuda grass & ++++ \\
\hline Typha elephantina & Elephant grass & +++ \\
\hline Saccharum bengalense & Munj Sweetcane & +++ \\
\hline Themeda anathera & Loonder Grass & +++ \\
\hline Dalbergia sissoo & North Indian rosewood & + \\
\hline Acacia catechu & Cutch tree & + \\
\hline Bombax Ceiba & Cotton tree & + \\
\hline Ficus benghalensis & Banyan tree & + \\
\hline Eugenia Jambolana & Black plum & + \\
\hline Oryza sativa & Asian rice & +++ \\
\hline Triticum aestivum & Wheat & +++ \\
\hline Zea Mays & Corn & ++++ \\
\hline
\end{tabular}

[20].

Note: ++++ (Highly preferred)

+++ (Moderately preferred).

+ (Not well preferred) 
individuals, for example, while that wild buffalo harm crops every year and grumble that wild creatures crush the wall. They probably overestimate their expenses. A similar case was studied in Royal Chitwan National Park [19]. The crop field attracts the herbivores. The wild buffaloes are attracted towards the village areas during the crop growing season (April-Oct.). The wild Buffalo come out of the Reserve mainly in pursuit of their supplemental seasonal food. Village respondents stated that the main reason for the field raids is the taste of succulent crop plants, soft and palatable for wild Buffalo. But there are other reasons among them that the main reason for the crop-raiding is that the jungle plant and grasses cannot fulfill all their daily food requirements and roam in field crops. One of the best examples for such roaming in field crops by wild Buffalo was found in the literature [20], as in Figure 1. Among adults, females tend to have longer horns than males, as shown in Figure 2, but males have much thicker horns (the basis for sexing in case genitalia are not visible), as in Figure 1.

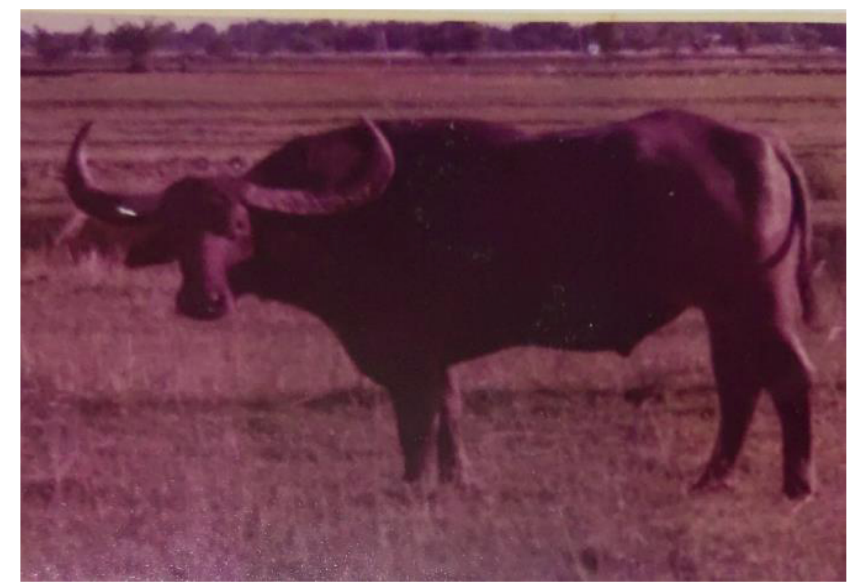

Figure 1: Male Asian Wild Buffalo (Bubalus Arnee) standing near crop field of the Haripur Village of Sunsari district of Nepal.

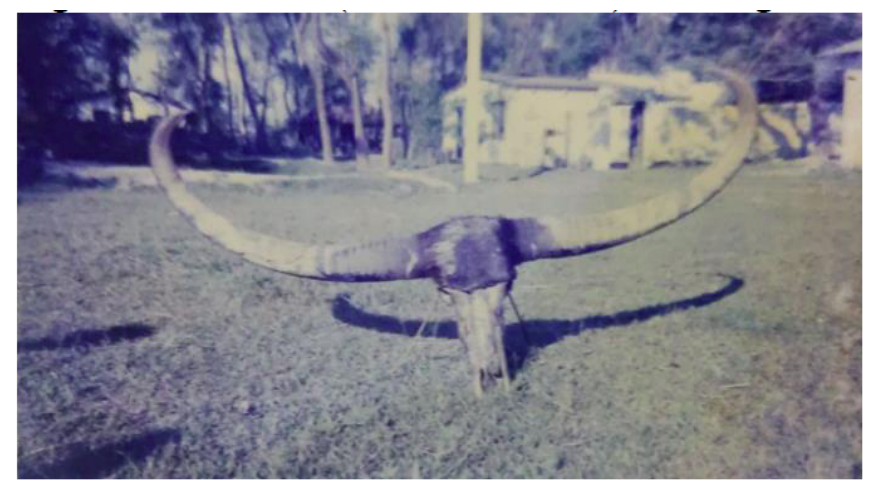

Figure 2: Longest horns of buffalo cow, collected in Koshi Tappu Wildlife Reserve. The animal died due to disease; the horn span measured about $5 \mathrm{ft}$.
The KTWR has had clashes with neighborhood networks since its foundation [21]. Individuals living nearer to KTWR are bound to uncover negative mentalities towards preservation. Educated people and farmers have a positive protection mentality somewhat while the family units with poor financial status and more prominent reliance on the KTWR for kindling, grub, and crude materials have a more negative demeanor towards preservation [22]. Helpless families are less worried about preservation, and institutional settings and miserable destitution close to secured zones seem to influence their perspectives. Hence, for the maintainable administration of KTWR and neighborhoods for normal asset preservation, financial advancement started in the mid-1990s. The Park People Project (PPP) and Buffer Zone Policy, under execution, have been compelling in a few different ways [23], and numerous villages have profited from the projects. This was proceeded by Participatory Conservation Project (PCP) and, as of late, by the CSUWN task to improve /save individuals' disagreements by cooperating to understand the twin target of preservation and advancement.

Since KTWR is little and is encircled by villages, wild vertebrates continuous croplands when the Reserve floods; in this manner, neighborhood individuals endure direct irritations because of the presence of KTWR, thus requiring isolation of the Reserve [21]. Wild Buffalo is likewise referred to as anthropogenic attack yields, for example, rice, sugarcane, and jute from agrarian grounds on the edges of their home reach, which has prompted buffalo human clashes in and around secured zones [24].

\section{ECONOMIC BENEFITS FROM BUBALUS ARNEE}

With the help of the CSUWN project, various preservation and work intercessions have been embraced to protect biodiversity, especially the wild buffalo populace in the KTWR. The administration plan of KTWR was at last affirmed in 2010 after a significant stretch. This endorsement has entitled the buffer zone networks to get half of the income acquired by the KTWR for network advancement. There is a reformist progression of sightseers, the two local people, and outsiders into the holding zone. By 2011, the Reserve has had the option to acquire a sum of NPR 11,75,933, contrasted with the year 2006, where just NPR 395,891 was produced. After the endorsement of the administration plan, the income has shot up to NPR 671,097 , twofold the figure procured in the year 2006. The diminishing in the income in the year 2009 is 
ascribed to the outcome of the floods that happened in September 2008, after a 2-km stretch of the Koshi River dike was washed away by the flood bringing about the immense immersion of the eastern stretch of the hold including human settlements and horticultural grounds. The income age is generally subject to the progression of the travel industry accordingly; extraordinary secured zones have various measures of income assortment. The test exists for the ensured territories that are asset poor, although they are as significant for preservation as the exceptionally visited zones. One approach to address the asset hole is to make a container store in which income created from asset-rich secured territories could help neighboring zones that are asset poor [25].

To lessen crop theft by wild creatures, a sun-based fueled electrified barrier has been raised in the high effect zone of the eastern area of the KTWR. This activity has fundamentally diminished the current nearby conflict among the neighborhood networks and holds the executives. Additionally, with the erection of the electrified barrier, no reports of yield plunder have been accounted for here, especially by wild buffaloes and elephants. Also, supported administration mediations, including a network-based antipoaching drive-by activating neighborhood young people, cradle zone networks, nearby instructors, and eco-clubs, have positively affected the clearing of wild cattle (cows and buffaloes) from the Reserve. The Reserve board, with the dynamic help of neighborhood networks, has had the option to gather a sum of NPR 128,000 from the punishments by seizing an aggregate of 426 cattle (both buffaloes and cows) from the Reserve. This was the first clearing drive ever directed by the Reserve as it is an exceptionally challenging policy-driven issue. Subsequently, there was a decrease in the quantity of feral and domesticated cattle recorded in the Reserve. Since no wood assets exist outside of the hold, there is a significant level of brushing pressure from both wild ones, just as homegrown stock. A multipronged approach towards decreasing the group size of the homegrown domesticated animals by supplanting it with a more profitable one along with the advancement of slow down taking care of training would, in the end, lessen the tension on the Reserve.

To address the above circumstance, KTWR has been advancing block plantation along the western limit of the Reserve to make a green belt to permit neighborhood individuals to gather grain for their animals, in this manner debilitating unlawful grazing. The blend of elective alternatives of making a utility zone for rotational cows munching and feed assortment supported by a solid law requirement system will at last counterbalance the current pressing factor applied on the hold. Under the aegis of the CSUWN project, a travel industry advancement system has been investigated to investigate the potential outcomes of creating the travel industry items that could profit neighborhood individuals and create nearby stewardship towards preservation. Moreover, different business improvement exercises for wetlandsubordinate networks, for example, fisheries, poultries, and wetland-based green undertaking, vegetable cultivating, have been upheld to improve the financial state of the individuals. The current expansion in the populace doesn't give comfort, as there are various difficulties to the drawn-out endurance of this species. A multipronged approach of preservation and advancement by assembling the buffer zone networks supported by a solid law requirement system would establish an ideal climate to address the current administration issues and concerns identified with assurance and protection. The primary goal ought to be towards upgrading preservation and saddling the sideeffects of protection for neighborhood advantage.

\section{WHY KOSHI TAPPU AREA IS BUFFER ZONE}

The KTWR has confronted Reserve-individuals clashes since its foundation. The impact of unsettling human influence changes extraordinarily, contingent upon nature and its force. Along these lines, understanding the above circumstance, the Government of Nepal in 2004 proclaimed an encompassing territory of $173.5 \mathrm{~km}^{2}$ as a buffer zone. This is one of the nation's inventive procedures for participatory preservation, underlining a buffer zone system intended to lessen the unfavourable effect of ensured territories on the occupations of nearby networks and the other way around. The complete human populace of the buffer zone in 2009 was 93,323 from 16,280 family units. As commanded by the Buffer Zone Management Regulations, the cushion zone is qualified for getting a half portion of the income produced by the KTWR for network advancement exercises. The cash got is diverted through client gatherings. These client bunches are shaped at the settlement level and are answerable for the arranging, the executives and the management of the exercises actualized. The Koshi River wanders and goes through the KTWR. The waterway not just shapes the actual highlights of the district yet, in addition, changes the biological system of the zone and profoundly affects the financial qualities of the neighborhood networks of 
the buffer zone inhabitants [13]. The Koshi River, which changes its course quickly across years, changed its fundamental course significantly during the storm of 2008 and penetrated a $2 \mathrm{~km}$ stretch and entered the human settlements through Kushaha Village [26].

This abrupt move throughout the Koshi River has profoundly affected the actual scene and impacts human settlement and farming. Enormous parcels of timberland close to Prakashpur Village and fields in the eastern piece of the district were completely washed away. The Koshi penetrate carried untold wretchedness and misfortune to the lives of individuals of Nepal as well as of India. After the break of the eastern dike, endeavors were made to return the primary channel to its unique course by utilizing many hefty machines and kinds of hardware supported by a solid armada of more than 1000 faculty for a time of more than one year. The Reserve needed to adapt to all the externalities like transitory settlements inside the Reserve, the stock of fuelwood and feed, extreme utilization of neighborhood assets by both nearby individuals just as the development organization occupied with the maintenance and support work of the penetrated bank. Throughout fix and upkeep, six male Arna was moved $5 \mathrm{~km}$ south of the flood (in Gobargarha Village) from their territory because of the significant level of aggravation. During this period, the Reserve needed to endure the worst part of this cataclysmic event. During political flimsiness and strife, all the security posts were harmed, and the security workforce was removed and converged inside the hold central command, Kushaha. Subsequently, the law requirement turned out to be exceptionally powerless because of which infringement, illicit brushing, collecting of assets got uncontrolled. The primary danger to the wild Buffalo is the kept blending and blending of the wild and the homegrown stocks bringing about hybridization.

What's more, because of the Koshi surge of 2008, there were theories of a wide-scale loss of this species. Subsequently, to discover the status, a registration was led mutually by the Department of National Parks and Wildlife Conservation (DNPWC) and the Conservation and Sustainable Use of Wetlands in Nepal (CSUWN)via the square check strategy [27]. The exclude was conveyed both by foot and with the utilization of elephants. The evaluation was led in AprilMay 2009, when permeability was the most noteworthy and water release was the least. A recurrent tally was accomplished for three back-to-back days.

\section{COMPLICATIONS ASSOCIATED WITH BUBALUS ARNEE}

Poaching is boundless in Nepal, frequently for resource purposes, to enhance either small weight control plans or deficient elective work openings. Ineffectual law authorization and deficient protection mindfulness are contributory variables. At Koshi Tappu, 763 wild creatures were accounted for executed somewhere in the range of 1994 and 1999, involving 683 wild hogs, 65 hoard deer, and 15 spotted deer, of which 81 (76 wild hogs, 3 hoard deer, and 2 spotted deer) were poached in 1999 alone. Wild Buffalo, turtles, and winged animals are likewise slaughtered. However, no records are kept since most poachers, and their casualties stay undetected by the Reserve specialists. Yearly mortality because of poaching is accepted to be a few times higher than what the records recommend and is one of the fundamental drivers for the exhaustion of the few feral life species in the Reserve. Poachers use traps, catches, lances, firearms, explosives, and toxins (basic pesticides) to murder focused species. Indeed, even the first Ramsar Site in Nepal, Koshi Tappu Wildlife Reserve, was made initially to secure the final populace of Asiatic Wild Water Buffalo and not for the insurance of wetland biodiversity. According to Protected Animal Species Under The National Parks And Wildlife Conservation Act, 1973: The Scientific name of Wild water Buffalo was Bubalus arnee changed into Arna as the local name. From IUCN status, it is Endangered [1].

\section{NECESSITY OF TRANSLOCATION OF WILD BUFFALO FROM KTWR}

Sufficient genetic diversity of wild individuals or feral backcrossed as suggested by Heinen and Paudel in 2015 [9] should be represented from a source population of KTWR to the translocated population in the native area such as Chitwan, Bardiya, or other appropriate sites [28] in Nepal. Founding genetic diversity of translocated population determined by the number of genetically variable wild individuals, the proportion of diverse pure stocks, those that contribute genetically to the next generation, and the number and frequency of polymorphic alleles representing whole genomes of the source population. Translocated populations are mostly small in size; therefore, they are prone to loss of genetic diversity very rapidly through genetic drift [29]. Genetic assessment of source populations in advance of translocation (pretranslocation) helps guide translocation plans and informed post translocation assessment or monitoring 
genetic diversity in the founders [30]. In addition to geneticists, conservation biologists, wildlife experts, wildlife veterinarians, ecologists, physiologists, and local people in the translocation program can ensure the re-introduced population's longer-term welfare and well-being.

Selecting individuals for translocation programs, identification of wild individuals through the detailed molecular study of the buffalo population protected in the Reserve is a high priority for the Nepal government. Also, understanding the genetic makeup of Wild Buffalo could be used as the basis for the genetic improvement of domestic stock. National capacity building to conduct advanced molecular studies should be initiated from collecting blood and fecal samples, creating a DNA reference library, and carrying out genetic research on various aspects such as population genetics, breeding behaviors among different buffalo types, disease dynamics, and food habits of buffalo population in the Reserve. Kandel et al. [5] presented DNA sequence variation in the partial but variable cytochrome $b$ gene among purely wild, feral, and domesticated individuals and prospects for advancing genetic research on Wild Buffaloes inhabiting KTWR in eastern Nepal.

Before embarking on a genetic translocation program for the Buffalo of KTWR, Nepal should upscale its laboratory facilities, design populationbased advanced genetic research, and take the initiative to build a DNA bank of all possible individuals counted in 2016. The DNA bank, reference DNA sequences, and genotype database are crucial for research and conservation efforts to enhance our understanding of genetic effects of introgression, study dietary patterns on different buffalo types, and assess the status of pathogens affecting the buffaloes with different genetic backgrounds. Using the same blood samples collected during this study, we have reported the prevalence of malaria parasites for the first time in buffaloes of KTWR [31]. Given the lack of highly technical laboratories and trained workforce in Nepal and the urgency to identify wild individuals reliably, collaborative research with international universities, research institutes, and conservation partners on advanced molecular studies are to be jointly conducted. Such research sets a baseline to develop well-defined action-oriented strategies that guide the pre-translocation genetic study of wild buffaloes in KTWR and their monitoring through post-translocation genetic studies. Kandel et al. [5] highlighted key actions like the collaboration between partners, the establishment of DNA bank for all extant individuals in
KTWR, involvement of experts from different disciplines, upscaling and strengthening present laboratories and building the capacity of available human resources for genomic level data management, which are important steps to be taken by the ministry of forest and environment, department of national parks' and wildlife conservation and its national and international conservation partners for genetic translocation of wild buffalo including other threatened species of Nepal.

Quick and complete immersion of the Reserve during storms and successive changes in stream courses pretty much consistently has been the greatest danger to the presence of wild Buffalo. The penetration of the eastern bank of the Koshi flood at Kusaha of Sunsari region on eighteenth August 2008 made destruction for untamed life and their territories, individuals' vocation, and government assistance. Khatri et al. [25] directed to learn the status of biodiversity inside KTWR and its Buffer Zone from March to November 2009 to think of Arna, dolphins, marsh mugger crocodile, Swamp francolin (Simtitra), and vulture populace and survey the biological status of wetlands. Direct tally strategy, cut across technique, point tallies, subjective samplings, field perception, and social overview was done to examine the biodiversity status. There was an aggregate record of 219 wild water buffalo, 11 dolphins, 5 marsh mugger crocodiles, 52 to 74 swamp francolin and 517 vultures. The examined wetlands were modestly dirtied. By and large, 42 taxa of benthic macroinvertebrates were recorded. The outcomes were additionally contrasted and a couple of long stretches of information before the flood event. The current outcome demonstrated an empowering populace of key species at the Reserve, yet the dangers for preservation stay testing.

Wild water buffalo lives together with the hold with exceptionally backcrossed non-domesticated wild Buffalo thought to have been delivered in KTWR during the 1950s [8]. Presently, the significant dangers to wild water buffalo are loss of hereditary variety because of introgression with homegrown and non-domesticated Buffalo, just as dangers from chasing and illnesses from homegrown animals $[31,32,33]$. The number of inhabitants in non-domesticated steers was discovered to be higher than the assessed populace in 2000 [17], which could be credited to law authorization and legitimate administration lacking. The act of crossrearing with wild males is as yet a typical practice [13] in KTWR. A sum of 15 wild water buffalo has been moved in a 30-ha nook on the old Padampur territory of 
Chitwan National Park (CNP), Nepal [10]. Park authority is preserving the natural surroundings like KTWR in various ways like fencing to shield them from the danger by various sources, cutting the grasses, keeping up water from Chure territory (The youngest mountains in Nepal and is located between the plain low lands in the south and the mid-hills in the north), building lakes for floundering and setting up view towers for better observation of them. However, the achievement is not hundred percent [10]. The introduction of three calves is incredible advancement; however, the demise of 6 individuals is as yet a reality that limits CNP from being another normal territory of wild water buffalo and keeps up its feasible populace [10]. In this way, there is a solid need to move a portion of the populace into another reasonable environment. A few analysts have suggested the movement of Buffalo into either Chitwan or Bardia National Park (BNP) [3,34]. Accordingly, it got important to discover the appropriate living space of the wild water buffalo in the region to be moved in BNP. At this point, it is set up that the utilization of satellite far off detecting and GIS is a viable device for territory assessment [35]. Subsequently, this investigation endeavors to locate the appropriate environment of Bubalus arnee inside the Babai flood plain of BNP utilizing GIS alongside distantly detected information and estimations acquired from the field.

Out of total $108.67 \mathrm{~km}^{2}$ of the investigation region of Babai flood plain, $8.26 \mathrm{~km}^{2}$ was discovered as the most suitable living area, $100.12 \mathrm{~km}^{2}$ was discovered as the tolerably appropriate environment and $0.29 \mathrm{~km}^{2}$ was discovered as the less appropriate natural surroundings for movement of wild water buffalo in Bardia National park [12].

\section{CONCLUSION}

Due to Nepal's weak management policy, the KTWR area is heading towards its doom. The Reserve, which is mainly reserved to support the last surviving population of Asian wild buffaloes, is not secured over there. The rules and regulations are not enforced strictly. One of the main problems of this Reserve is the uncontrolled grazing of the vegetation by domestic cows and buffaloes. The herds of domestic buffaloes and cows graze inside the Reserve and reside inside the Tappu for almost the whole of a year until the monsoon season arrives. The local trend of the people has become so worst that they buy herds of domestic buffaloes and cows and just send them to the Reserve to service. The exact population of these domestic cattle inside is unknown. For the preservation of wild Buffalo in Koshi Tappu Wildlife Reserve, two major problems are identified (a) problem affecting the daily life of the people and (b) the problem created by people by poaching of wild animals, illegal use of forest resources, habitat destruction, forest, fire and river fishing. The surge of 2008 has some information that further confounded the issue as the Reserve needed to adapt all the externalities going from the impermanent settlement, fuelwood and feed supply, extreme utilization of neighborhood assets and the development of the dike. Although KTWR gives a significant environment to various jeopardized species, current practices and existing issues represent a genuine danger to the drawn-out protection of biodiversity. On the off chance that we are to deal with the biodiversity and improve the neighborhood work of wetlandsubordinate individuals, the whole stretch of the Koshi River from Chatara to Koshi flood ought to be given due consideration and need. Likewise, the current nondomesticated cows ought to be eliminated to make and provide enough space for wild herbivores. The movement of Arna to comparable natural surroundings somewhere else ought to likewise be a need from the administration viewpoint. The Government needs to spend funds searching for more possible areas of translocation of Wild Water Buffalo.

\section{CONFLICT OF INTEREST}

The authors do not have any conflict of interest.

\section{FUNDING STATEMENT}

The funds were not received by any funding agency for the present research.

\section{ACKNOWLEDGEMENT}

Thanks go out to the Chief of the Koshi Tappu Wildlife Reserve Office in Sunsari, Nepal on his continuous guidance during our visit to the reserve and for supplying necessary research documents.

\section{REFERENCES}

[1] IUCN Nepal. A Review of the Status and Threats to Wetlands in Nepal, International Union for Conservation of Nature Kathmandu, Nepal, 2004.

[2] Heinen JT. Nature Preserves 1995; pp. 551-561. In: Nierenberg, W.A. (ed.). Encyclopedia of Environmental Biology. Academic Press, San Diego, California, USA

[3] Heinen JT. Population viability and management recommendations for wild water buffalo Bubalus bubalis in Kos Tappu Wildlife Reserve, Nepal. Biological Conservation 1993; 65: 29-34.

https://doi.org/10.1016/0006-3207(93)90193-5 
[4] Koshi Tappu Wildlife Reserve and its Buffer zone management plan (2074/75- 2078/79), Government of Nepal, Ministry of Forests and Environment, Department of National Parks and Wildlife Conservation, Koshi Tappu Wildlife Reserve Office, 2018.

[5] Kandel RC, Poudel RC, Sadaula A, Kandel P, Gairhe KP, Pokheral CP, et al. Revisiting genetic structure of Wild Buffaloes Bubalus arnee Kerr, 1792 (Mammalia: Artiodactyla: Bovidae) in Koshi Tappu Wildlife Reserve, Nepal: an assessment for translocation programs. J Threat Taxa 2019; 11: 14942-54. https://doi.org/10.11609/jott.4940.11.15.14942-14954

[6] DNPWC. Wild Water Buffalo (Bubalus arnee) Conservation Action Plan for Nepal (2020- 2024), Department of National Parks and Wildlife Conservation, Babarmahal, Kathmandu, Nepal, 2020.

[7] Bhuju UR, Shakya PR, Basnet TB, Shrestha S. Nepal Biodiversity Resource Book, Publisher: Earthprint Limited, ISBN: 9789291150335, 2007

[8] Dahmer T. Status and Distribution of the Wild Buffalo (Bubalus bubalis) in Nepal. MSc Thesis, University; 1978.

[9] Heinen JT, Paudel PK. On the translocation of wild Asian Buffalo Bubalis arnee in Nepal: Are feral backcrosses worth conserving? Conservation Science 2015; 3(1): 11-21.

[10] Shah R, Tripathi S, Bhata B.Translocation of Wild Asian Buffalo (Bubalus arnee): a way forward to conservation in Nepal, 2017; pp. 175-178. In: Proceedings of the International Buffalo Symposium, 242pp.

[11] Kandel RC, Solanki GS, Chalise MK, Sharma BK. Population and Demography of Asian Wild Buffalo (Bubalus arnee Kerr, 1792) at Koshi Tappu Wildlife Reserve, Nepal. Journal of Emerging Trends in Economics and Management Sciences 2018; 9(4): 212-218.

[12] Thapa R, Neupane B, Ranabhat S, Poudel M, Panthi S. Habitat suitability of wild water buffalo (Bubalus arnee) in Babai flood plain of Bardia National Park, Nepal. Global Ecology and Conservation 2020; 23: e01172. https://doi.org/10.1016/i.gecco.2020.e01172

[13] Khatri TB, Shah DN, Mishra N. Wild Water Buffalo Bubalus arnee in Koshi Tappu Wildlife Reserve, Nepal: status, population and conservation importance. J Threat Taxa 2012; 04: 3294-301. https://doi.org/10.11609/JoTT.02990.3294-301

[14] Heinen JT, Shrestha SK. Evolving policies for conservation: An Historical Profile of the Protected Area System of Nepal. Journal of Environmental Planning and Management 2006; 49: 41-58. https://doi.org/10.1080/09640560500373048

[15] Bronson FH. Mammalian reproductive biology. University of Chicago Press; 1989.

[16] Cockrill WR. The husbandry and health of the domestic Buffalo. FAO, Rome, Italy; 1974.

[17] Heinen JT, Singh GR. A census and some management implications for wild Buffalo (Bubalus bubalis) in Nepal. Biological Conservation 2001: 101: 391-4. https://doi.org/10.1016/S0006-3207(01)00078-7

[18] Limbu KP, Karki TB. Park-people Conflict in Koshi Tappu Wildlife Reserve. Our Nature 1970; 1: 15-8. https://doi.org/10.3126/on.v1i1.298

[19] Mishra HR, Jefferies M. Royal Chitwan national park: Wildlife heritage of Nepal. Mountaineers Books; 1991.

[20] Kherwar P K. Endangered environment of Wild Buffalo of Koshi Tappu with reference to Anthropological impacts, Central Department of Zoology, MSc Thesis; 1996.
[21] Heinen JT. Park-People Relations in Kosi Tappu Wildlife Reserve, Nepal: A Socio-economic Analysis. Environ Conserv 1993; 20: 25-34

https://doi.org/10.1017/S037689290003719X

[22] Shrestha RK, Alavalapati JRR. Linking Conservation and Development: An Analysis of Local People's Attitude Towards Koshi Tappu Wildlife Reserve, Nepal. Environ Dev Sustain 2006; 8: $69-84$ https://doi.org/10.1007/s10668-005-0188-5

[23] Heinen JT, Mehta JN. Emerging Issues in Legal and Procedural Aspects of Buffer Zone Management with Case Studies from Nepal. The Journal of Environment \& Development 2000; 9: 4567.

https://doi.org/10.1177/107049650000900103

[24] Choudhury A, Barker JS. Wild water buffalo Bubalus arnee (Kerr 1792). Ecology, Evolution, and Behavior of Wild Cattle 2014: 255-301.

https://doi.org/10.1017/CBO9781139568098.018

[25] Khatri TB, Shah DN, Shah RDT, Mishra N. Biodiversity of Kosh Tappu Wildlife Reserve: a post-flood assessment. J Wetlands Ecol 2011; 4: 69-82.

https://doi.org/10.3126/jowe.v4i0.3734

[26] Khatri TB, Shah DN, Mishra N. Post-flood status of the Endangered Ganges River Dolphin Platanista gangetica gangetica (Cetartiodactyla: Platanistidae) in the Koshi River, Nepal. J Threat Taxa 2010; 2: 1365-71 https://doi.org/10.11609/JoTT.02496.1365-71

[27] Mickleburgh S. Mammals of the Southern African Subregion by $\mathrm{J}$. D. Skinner and R. H. N. Smithers (University of Pretoria, 1990 ISBN 0869798022,771 pp., HB £58.50. Oryx 1992; 26: 122-3. https://doi.org/10.1017/S0030605300023486

[28] Heinen JT. Phenotypic and behavioural characteristics used to identify wild buffalo Bubalus bubalis from feral backcrosses in Nepal. Journal- Bombay Natural History Society 2002; 99(2): 173-83.

[29] Frankham R, Ballou SE, Briscoe DA, Ballou JD. Introduction to conservation genetics. Cambridge university press; 2002 Mar 14. https://doi.org/10.1017/CBO9780511808999

[30] Groombridge JJ, Raisin C, Bristol R, Richardson DS. Genetic Consequences of Reintroductions and Insights from Population History. Reintroduction Biology, John Wiley \& Sons, Ltd; 2012, p. 395-440. https://doi.org/10.1002/97814443555833.ch12

[31] Kandel RC, Shrestha M, Sadaula A, KC M, Maharjan J, Solanki $\mathrm{GS}$, et al. First report of malaria parasites in water buffalo in Nepal. Veterinary Parasitology: Regional Studies and Reports 2019; 18: 100348 https://doi.org/10.1016/i.vprsr.2019.100348

[32] Kaul R, Williams AC, Rithe K, Steinmetz R, Mishra R. Bubalus arnee. The IUCN Red List of Threatened Species2019: e. T3129A46364616.

[33] Flamand JRB, Vankan D, Gairhe KP, Duong H, Barker JSF. Genetic identification of wild Asian water buffalo in Nepal. Animal Conservation 2003; 6: 265-70. https://doi.org/10.1017/S1367943003003329

[34] Aryal A, Shrestha TK, Ram A, Frey W, Groves C, Hemmer H, Dhakal M, Koirala RK, Heinen J, Raubenheimer D. Call to conserve the wild water buffalo (Bubalus arnee) in Nepal. International Journal of Conservation Science 2011; 2(4).

[35] Kushwaha SP, Roy PS. Geospatial technology for wildlife habitat evaluation. Tropical Ecology 2002; 43(1): 137-50.

\section{https://doi.org/10.6000/1927-520X.2021.10.08}

(C) 2021 Kherwar and Bhattarai; Licensee Lifescience Global.

This is an open access article licensed under the terms of the Creative Commons Attribution Non-Commercial License (http://creativecommons.org/licenses/by-nc/3.0/) which permits unrestricted, non-commercial use, distribution and reproduction in any medium, provided the work is properly cited. 